\title{
Treatment of dental and skeletal bimaxillary protrusion in patient with Angle Class I malocclusion
}

\author{
Claudio José Ramos ${ }^{1}$
}

In the orthodontic clinic, skeletal and dental bimaxillary protrusion is presented frequently as one of the factors leading patients to seek orthodontic treatment, mainly due to the esthetic involvement it has. The patient of this article illustrates this situation, being deeply uncomfortable with her esthetic appearance, due to the excessive upper incisors exposure and problems with lip sealing. This case was presented to the Brazilian Board of Orthodontics and Facial Orthopedics (BBO), as part of the requisites to become a BBO Diplomate.

Keywords: Class I malocclusion. Corrective orthodontics. Esthetics.

$\mathrm{Na}$ clínica ortodôntica, a biprotrusão esquelética e dentária, rotineiramente, aparece como um dos fatores que levam os pacientes a buscarem o tratamento ortodôntico, principalmente pelo envolvimento estético que provoca. A paciente apresentada neste artigo ilustra essa situação, pois estava bastante insatisfeita com sua estética, devido à exposição excessiva dos incisivos superiores e dificuldade em selar os lábios. Esse caso foi apresentado à Diretoria do Board Brasileiro de Ortodontia e Ortopedia Facial (BBO) como parte dos requisitos para a obtenção do título de Diplomado pelo BBO.

Palavras-chave: Má oclusão Classe I de Angle. Ortodontia corretiva. Estética.

\section{INTRODUCTION}

Caucasian female patient, 33 years and 5 months old, with the chief complaint: "I want to correct my teeth, because they are sticking out, and also improve my esthetics". The clinical exam showed the need of closing preexisting spaces, due to dental extractions, and reducing bimaxillary and dental protrusion. Anamnesis showed good general health.

\footnotetext{
${ }^{1}$ Former Professor of the Specialization Course in Orthodontics, APCD-DF. Former President of ABOR-DF. Specialist in Orthodontics, APCD-Bauru/São Paulo. Political Scientist, Graduated in the Federal District University Center (UDF). BBO Diplomate.

* Clinical case approved by the Brazilian Board of Orthodontics.
}

How to cite this article: Ramos CJ. Treatment of dental and skeletal bimaxillary protrusion in patient with Angle Class I malocclusion. Dental Press J Orthod. 2013 Nov-Dec;18(6):130-7.

\section{DIAGNOSIS}

The patient's facial aspect, in frontal view, did not present visible asymmetry, but absence of passive lip sealing. From the lateral view, the patient presented a convex profile, normal nasolabial angle, lack of lip sealing at rest, and increased lower anterior facial height (Fig 1). The patient presented a Class I molar relationship and $5 \mathrm{~mm}$ overjet; slight upper and

» The author reports no commercial, proprietary or financial interest in the products or companies described in this article.

» The patient displayed in this article previously approved the use of her facial and intraoral photographs.

Contact address: Claudio José Ramos

SGAS 607, Centro Clínico Metrópolis, Sala 217 - Brasília /DF - CEP: 70.200-670

E-mail: ramos.16@brturbo.com.br 
lower crowding; moderate Curve of Spee; absence of teeth \#36 and \#37; posterior cross bite on the right side, with buccal cross bite between teeth \#15 and \#45; lower midline deviated $1 \mathrm{~mm}$ to the left; and upper and lower incisors with incisal wear (Fig 2). The periapical and panoramic radiographs demonstrated root shortening of the upper right central incisor, absence of teeth \#36 and \#47, lower molar mesialization and lack of parallelism between roots (Figs 3 and 4).
In skeletal terms, according to the lateral cephalometric radiograph and respective tracing (Fig 5), it was observed that the patient presented unbalanced skeletal bases, characterized by angles SNA $=90^{\circ}, \mathrm{SNB}=83^{\circ}$ and $\mathrm{ANB}=7^{\circ}$, with a dolichofacial pattern, and presenting protruded upper incisors, with slight lingual tipping, and protruded lower incisors with buccal tipping. ${ }^{1}$ The functional analysis of mandibular movements revealed absence of anterior guides.
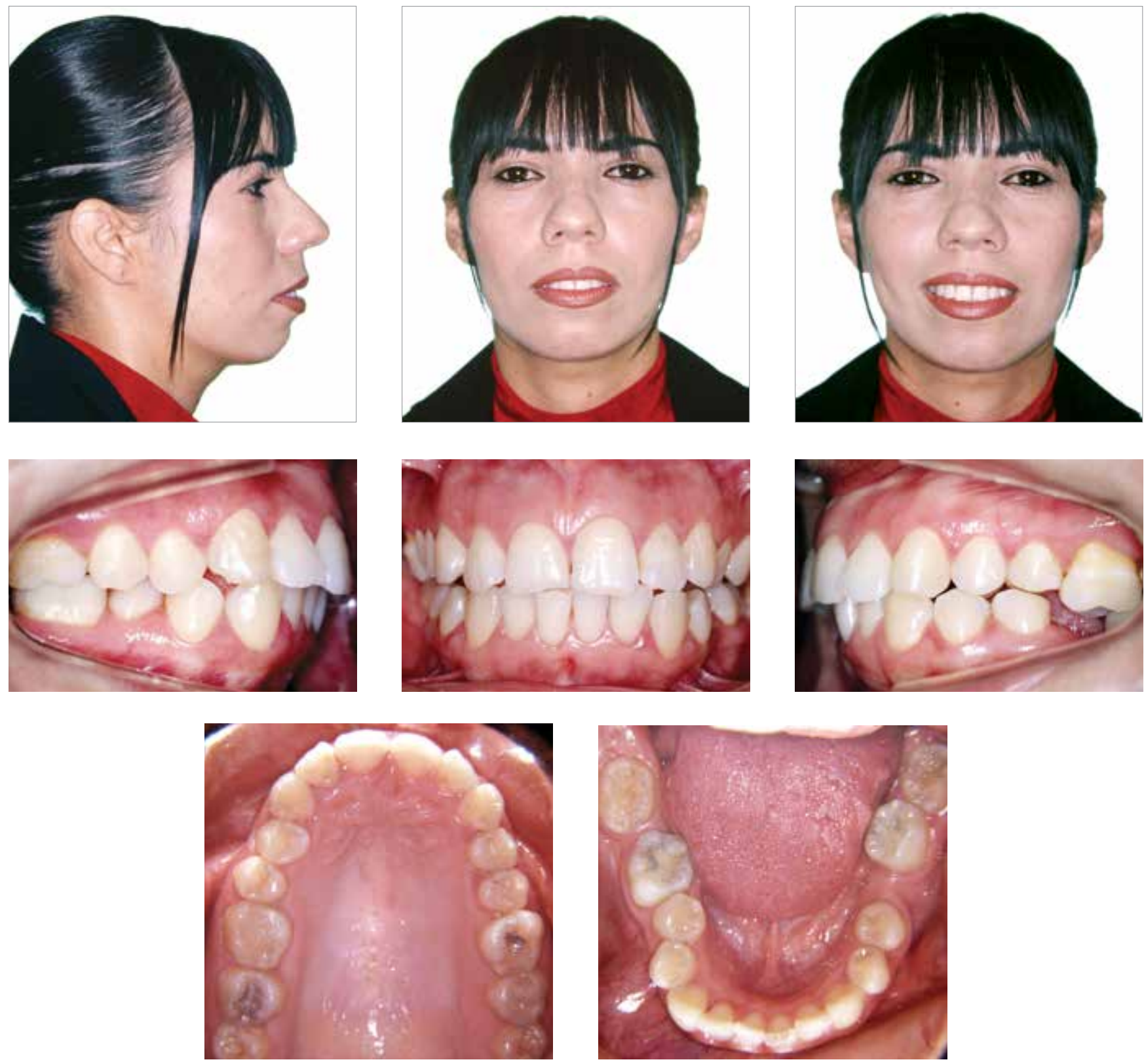

Figure 1 - Initial facial and intraoral photographs. 

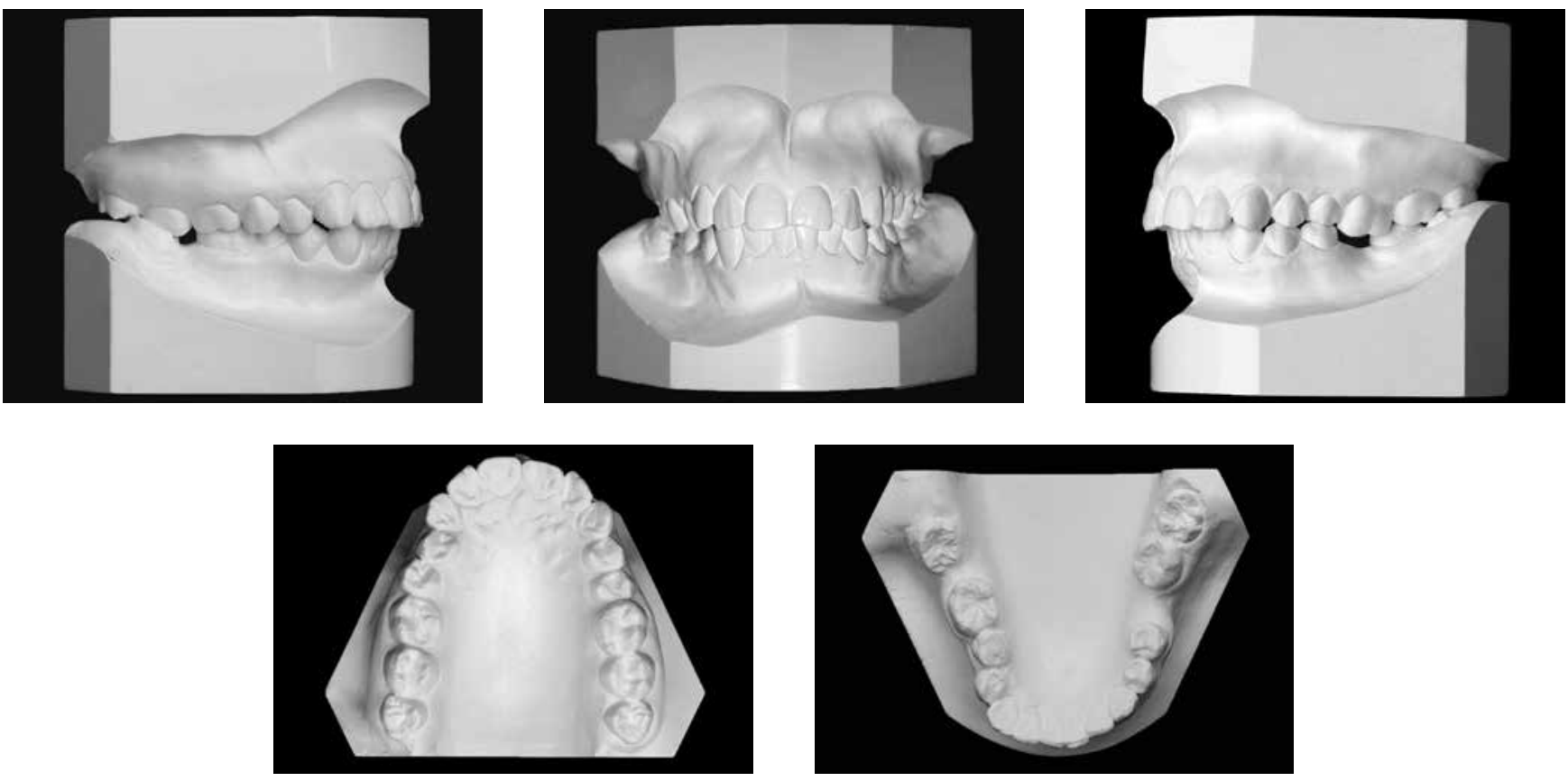

Figure 2 - Initial casts.
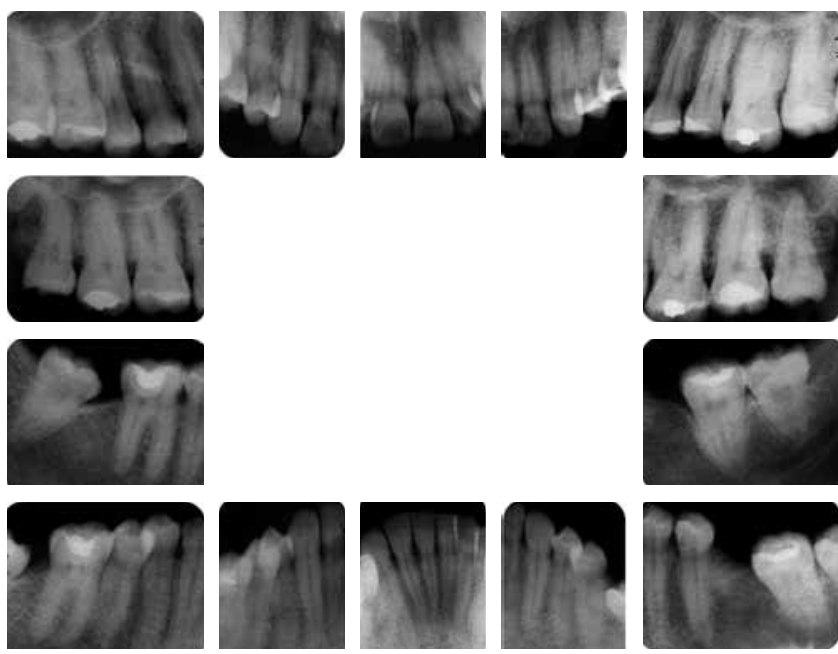

Figure 3 - Initial periapical radiographs

\section{TREATMENT PLAN}

Due to compromised facial esthetics and dental and skeletal bimaxillary protrusion, the treatment plan had the following objectives: Maintain canine occlusion; align and level the teeth; eliminate posterior cross bites; reduce overbite and overjet; eliminate crowding on both arches; level the Curve of Spee, close the spaces due to extraction of teeth \#36 and \#47, and also achieve lower molar root parallelism.

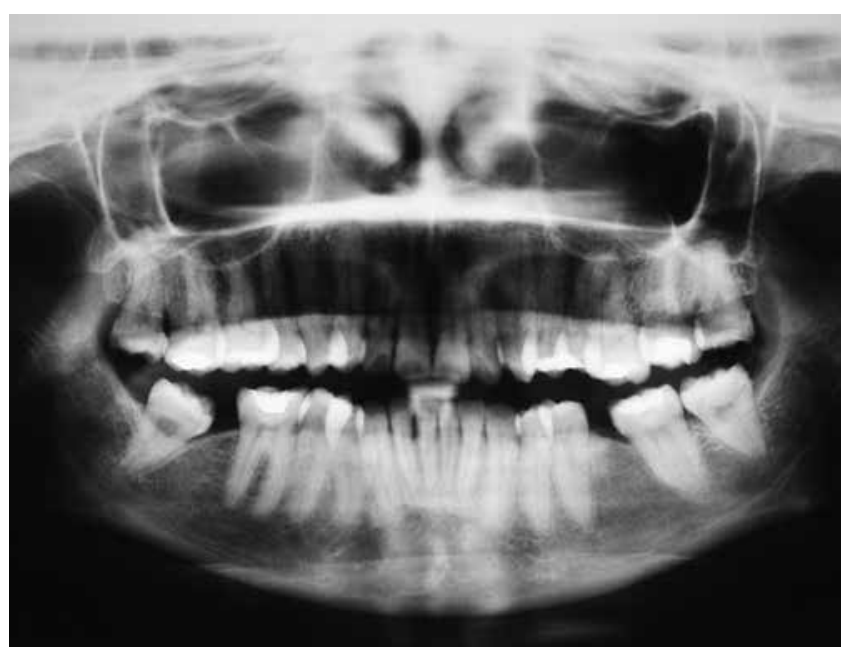

Figure 4 - Initial panoramic radiographs

For this purpose, extractions of the first upper and right lower premolars were necessary, besides the retraction of upper and lower anterior teeth, to reduce bimaxillary protrusion and correct the lower midline. All this very carefully, in order to avoid root shortening of tooth \#11.

The treatment also aimed at obtaining lateral and protrusion guides, and reduction of facial convexity. The nasolabial angle would be preserved, as well as 

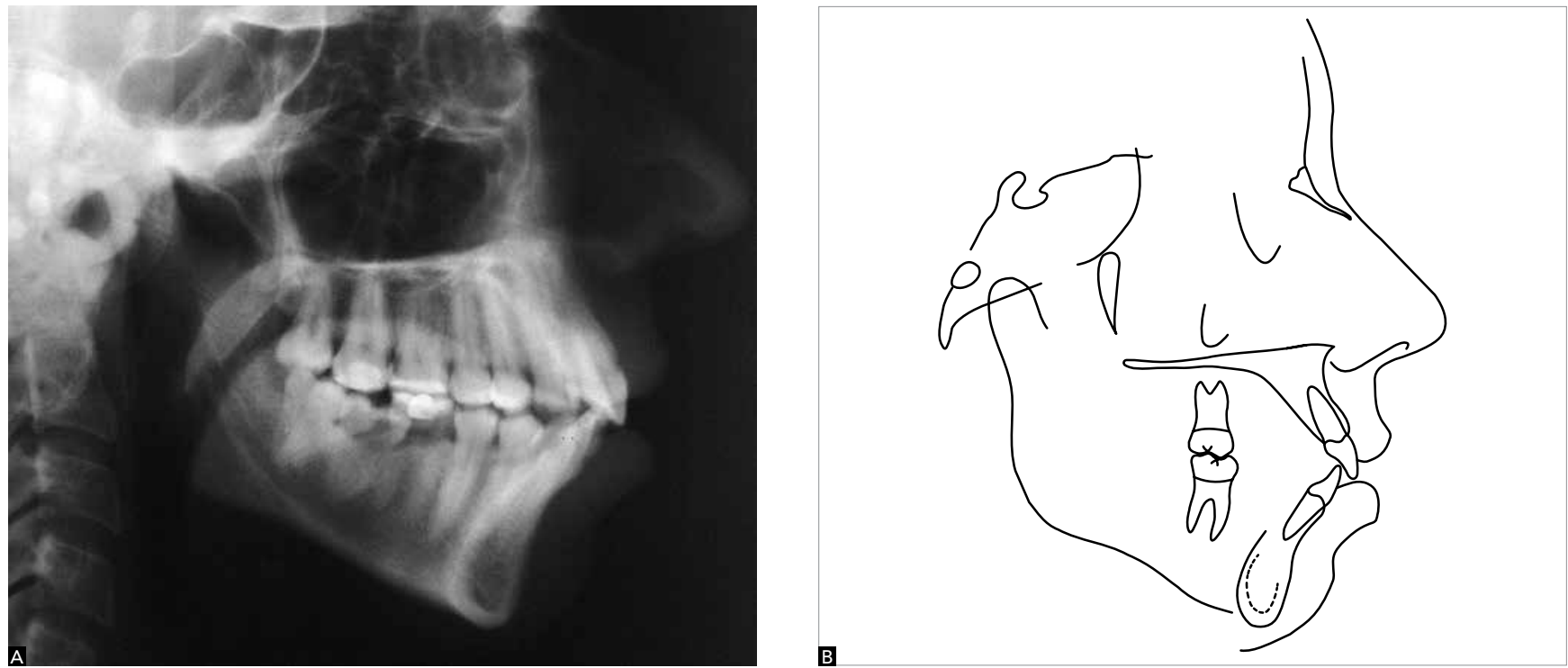

Figure 5 - Initial lateral cephalometric radiograph (A) and cephalometric tracing (B)

passive lip sealing would be expected and decrease of the lower anterior facial height, in order to reach smile harmony.

\section{TREATMENT PROGRESS}

The treatment was performed with the Straight wire technique, using metallic orthodontic brackets in both arches, according to Roth's prescription (0.022 x 0.028-in), with a removable transpalatal bar (stainless steel archwire, 0.032-in) as upper arch anchorage, and a lip bumper as lower arch anchorage. Leveling and alignment were carried with a sequence of NiTi round archwires, NiTi rectangular archwires $0.017 \times 0.025$-in and stainless steel rectangular archwires $0.019 \times 0.025$, with loops for retraction of anterior teeth and 5/16-in elastics to assist in the finishing.

Bands were placed on the first and second upper molars, as well as on the first, second and third lower molars, with a transpalatal bar on the first upper molars and lip bumper on lower molars.

The placement of the fixed orthodontic appliance was completed with the direct bonding of brackets on the remaining upper and lower teeth, except on teeth \#14, \#24 and \#44 - which would be extracted, with the objective of eliminating crowding and allow the correction of the dental bimaxillary protrusion, by means of retracting the anterior teeth. ${ }^{1,3,4}$ Alignment and leveling were carried with $0.012,0.014,0.016$ and 0.018 -in $\mathrm{NiTi}$ archwires; and $0.017 \times 0.025$-in NiTi rectangular, and stainless steel $0.019 \times 0.025$-in archwires. Then, the retraction of upper and lower anterior teeth, and the correction of the lower midline were performed. The extraction of tooth \#18 was suggested because it would be without its antagonist due to the mesial movement of tooth \#48. For intercuspation, 5/16-in intermaxillary elastics were used.

A stainless steel 0.028-in fixed lower retainer was bonded to teeth \#33 to \#45, and to teeth \#35 to \#37. On the upper arch, a wraparound removable plate was used.

\section{OBTAINED RESULTS}

The evaluation of the final records shows that there was $1^{\circ}$ reduction for SNA and SNB angles, a slight decrease in the vertical direction (Table 1). The canine guidance was kept, there was overjet reduction and overbite and Curve of Spee correction. All teeth were aligned and leveled, and the posterior cross bites eliminated; the crowding 
on both arches was corrected; Curve of Spee was leveled. The spaces for teeth \#36 and \#47, and also the extraction spaces for teeth \#14, \#24 and \#44 were properly closed; upper and lower anterior retraction was satisfactory.

The lower midline correction and anterior guides were obtained. However, lip sealing was not completely passive, due to the patient's vertical growth pattern. The nasolabial angle was preserved, despite the decrease of incisor protrusion, which promoted smile harmony (Figs 6 to 10). The treatment lasted 35 months.

\section{FINAL CONSIDERATIONS}

The treatment of dental skeletal bimaxillary protrusion was successful, once the main objectives proposed to the patient were achieved, resulting in good occlusion and pleasant facial esthetics (Fig 6). A good parallelism was obtained between roots, especially for lower molars. The pre-existing spaces before treatment and those caused by the extraction of teeth \#14, \#24 and \#44 were properly closed, with upper and lower anterior retraction (Fig 7).
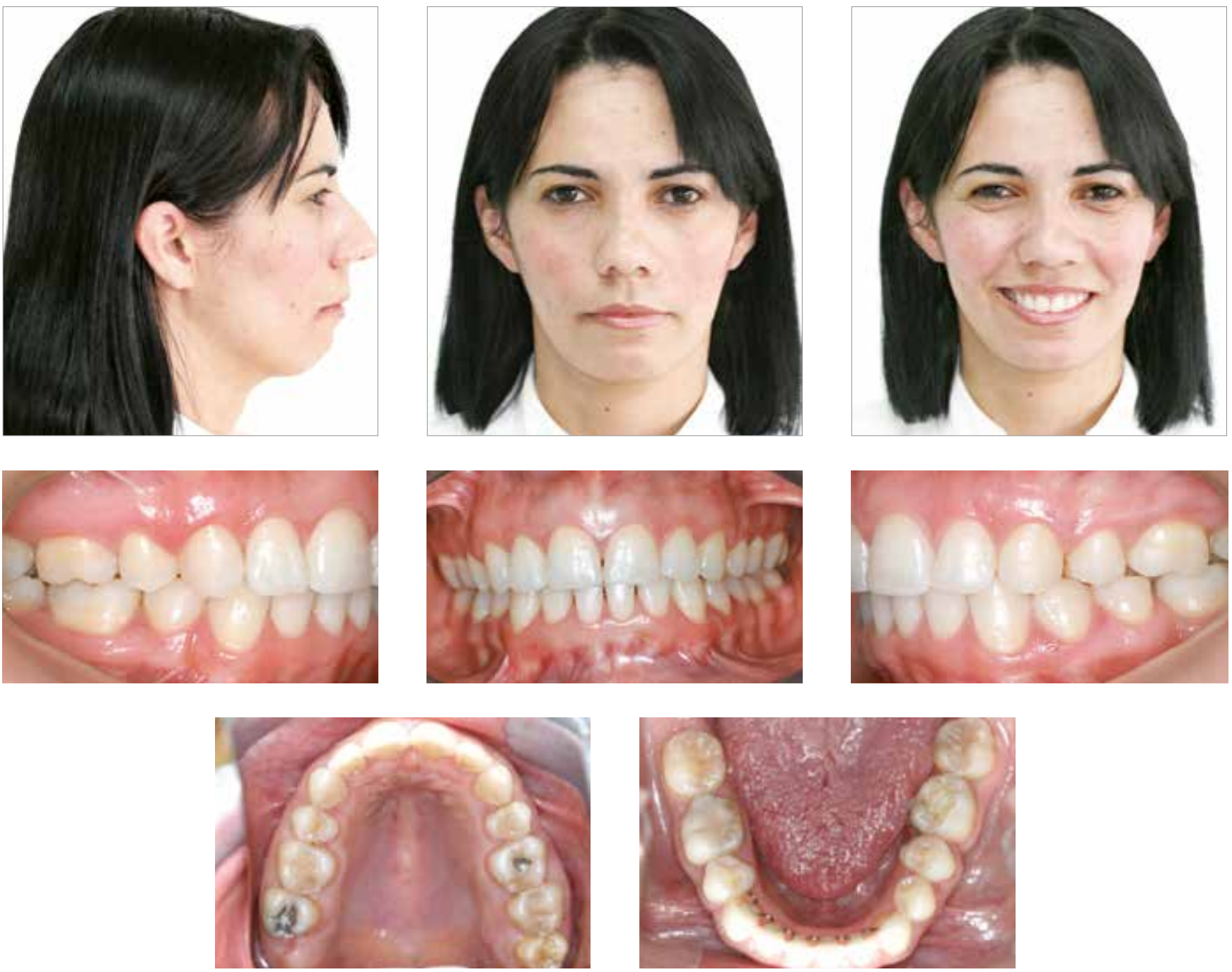

Figure 6 - Final facial and intraoral photographs. 

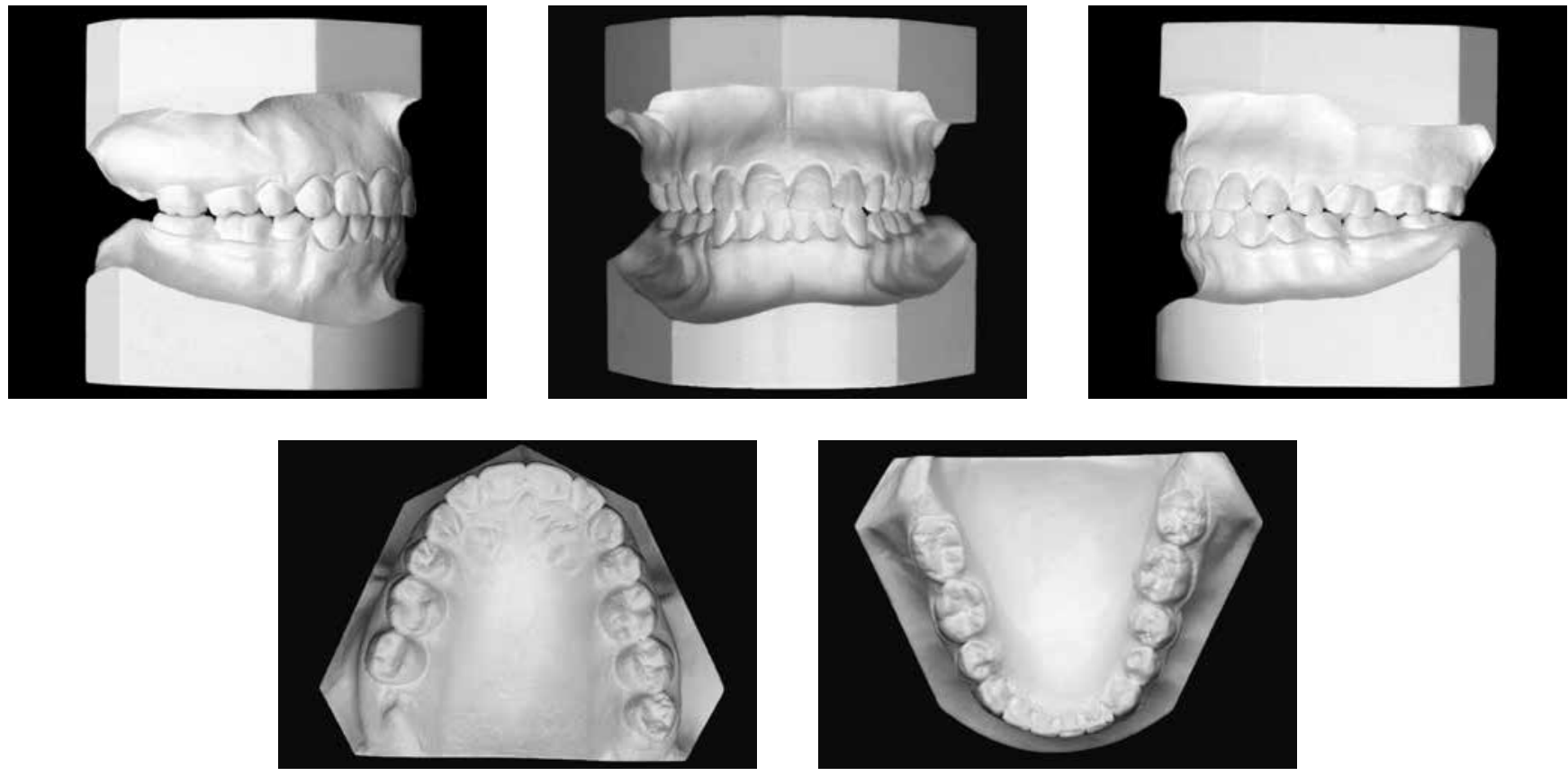

Figure 7 - Final casts
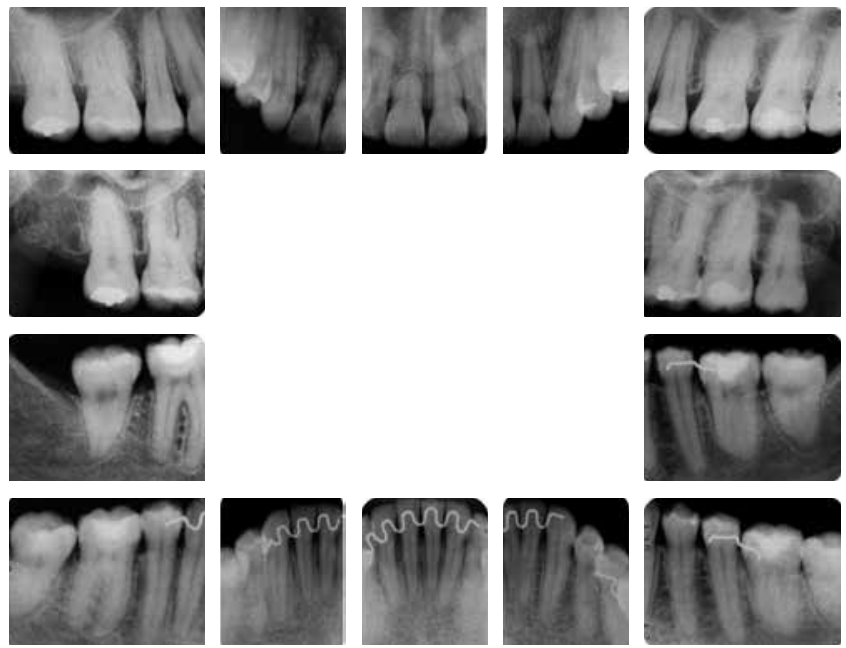

Figure 8 - Final periapical radiographs.

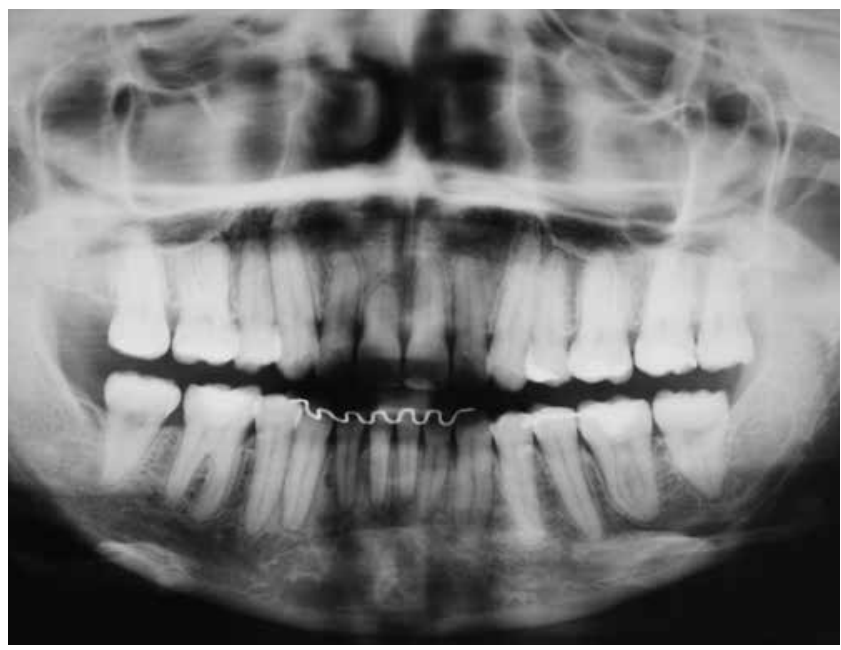

Figure 9 - Final panoramic radiograph. 

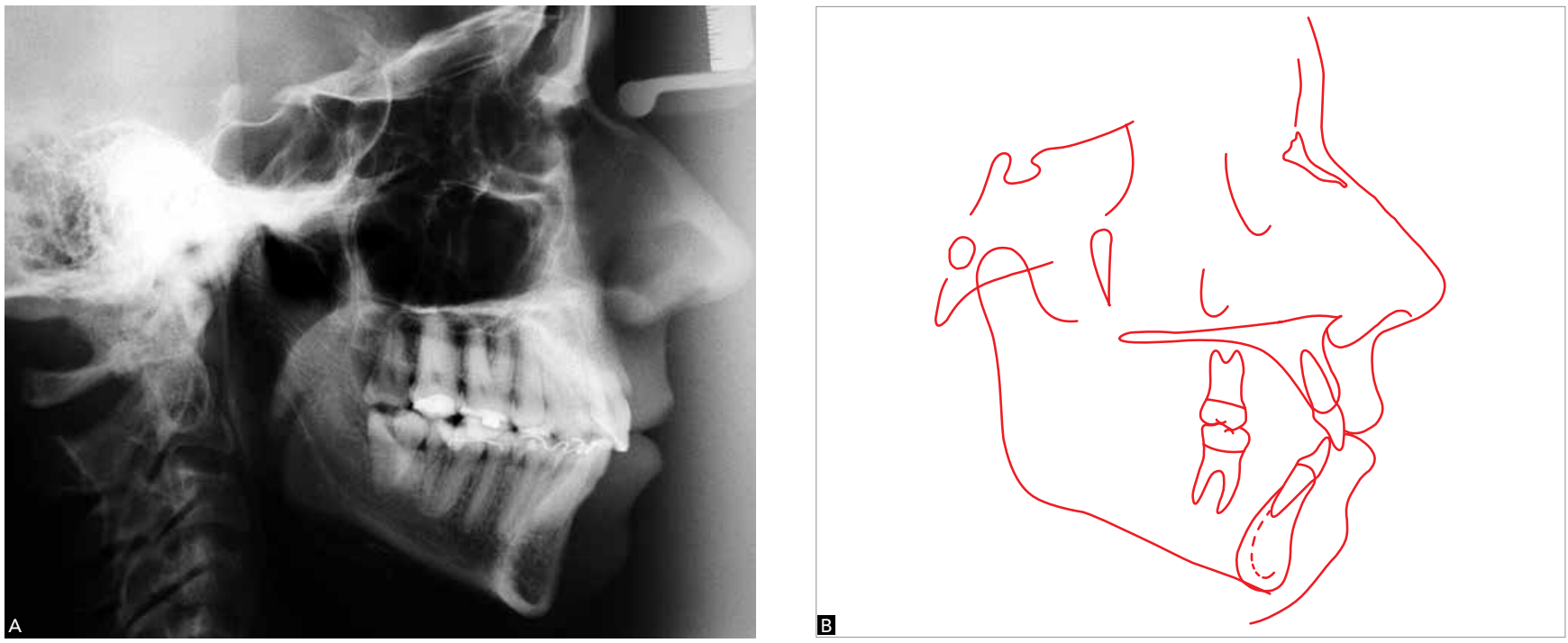

Figure 10 - Final lateral cephalometric radiograph (A) and cephalometric tracing (B).

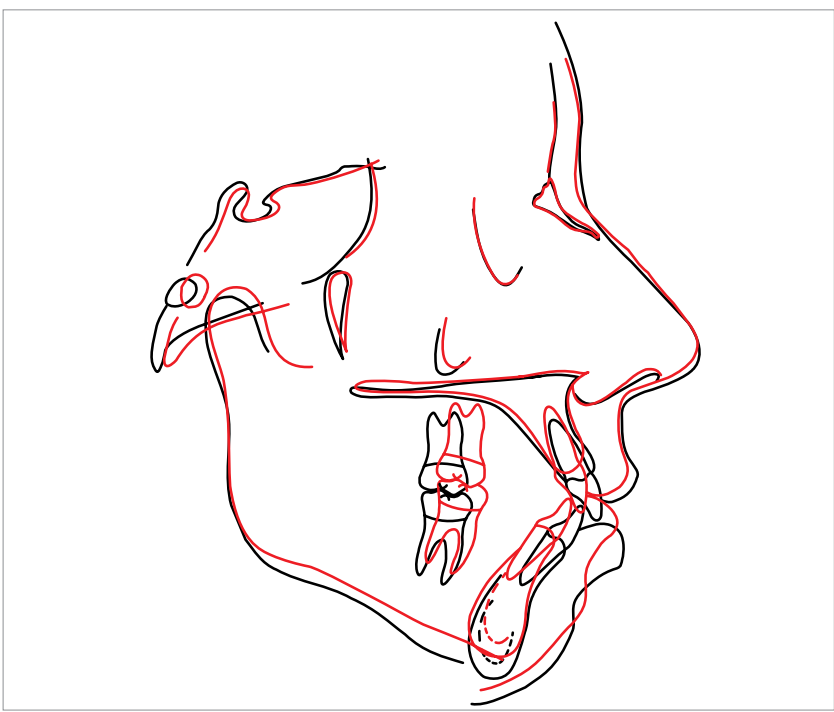

Figure 11 - Total superimposition of initial (black) and final (red) cephalometric tracings, registered on SN line.

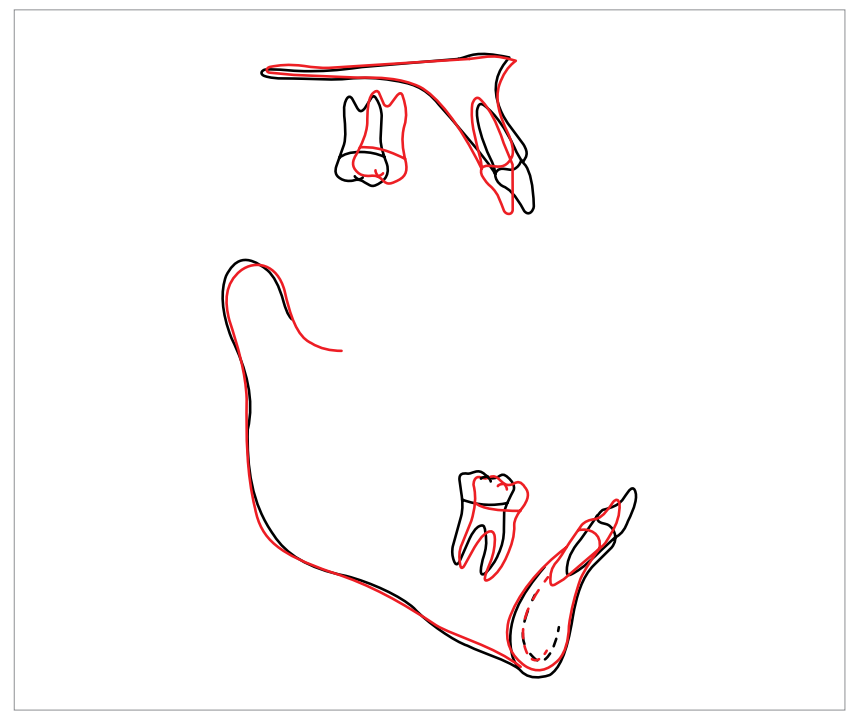

Figure 12 - Partial superimposition of the maxilla (A) and the mandible (B), of initial (black) and final (red) cephalometric tracings, evidencing tooth movements.

The level of root resorptions was acceptable, except for the upper right central incisor, in which the root shortening increased significantly, ${ }^{7,9}$ but without any mobility observed in regular evaluation of each treatment phase (Fig 8). The patient was pleased with the treatment result, since it improved her facial esthetics 
Table 1 - Cephalometric measures

\begin{tabular}{|c|c|c|c|c|c|c|}
\hline & Measures & & Normal & $\mathbf{A}$ & $\mathbf{B}$ & A/B diff. \\
\hline \multirow{8}{*}{ Skeletal pattern } & SNA & (Steiner) & $82^{\circ}$ & $90^{\circ}$ & $89^{\circ}$ & 1 \\
\hline & SNB & (Steiner) & $80^{\circ}$ & $83^{\circ}$ & $82^{\circ}$ & 1 \\
\hline & ANB & (Steiner) & $2^{\circ}$ & $7^{\circ}$ & $7^{\circ}$ & 0 \\
\hline & Facial angle & (Downs) & $0^{\circ}$ & $15^{\circ}$ & $16^{\circ}$ & 1 \\
\hline & $Y$ axis & (Downs) & $59^{\circ}$ & $60^{\circ}$ & $57^{\circ}$ & 3 \\
\hline & Facial angle & (Downs) & $87^{\circ}$ & $88^{\circ}$ & $88^{\circ}$ & 0 \\
\hline & SN-GoGn & (Steiner) & $32^{\circ}$ & $32^{\circ}$ & $30^{\circ}$ & 2 \\
\hline & FMA & (Tweed) & $25^{\circ}$ & $25^{\circ}$ & $24^{\circ}$ & 1 \\
\hline \multirow{7}{*}{ Dental pattern } & IMPA & (Tweed) & $90^{\circ}$ & $101^{\circ}$ & $103^{\circ}$ & 2 \\
\hline & 1.NA (degrees) & (Steiner) & $22^{\circ}$ & $21^{\circ}$ & $14^{\circ}$ & 7 \\
\hline & 1-NA (mm) & (Steiner) & $4 \mathrm{~mm}$ & $7 \mathrm{~mm}$ & $3 \mathrm{~mm}$ & 4 \\
\hline & 1.NB (degrees) & (Steiner) & $25^{\circ}$ & $35^{\circ}$ & $35^{\circ}$ & 0 \\
\hline & I-NB (mm) & (Steiner) & $4 \mathrm{~mm}$ & $12 \mathrm{~mm}$ & $9 \mathrm{~mm}$ & 3 \\
\hline & $\frac{1}{1}$ - Interincisal angle & (Downs) & $130^{\circ}$ & $117^{\circ}$ & $126^{\circ}$ & 9 \\
\hline & I-APo (mm) & (Ricketts) & $1 \mathrm{~mm}$ & $8 \mathrm{~mm}$ & $4 \mathrm{~mm}$ & 4 \\
\hline \multirow{2}{*}{ Profile } & Upper lip - S line & (Steiner) & $0 \mathrm{~mm}$ & $2 \mathrm{~mm}$ & $0 \mathrm{~mm}$ & 2 \\
\hline & Lower lip - S line & (Steiner) & $0 \mathrm{~mm}$ & $5 \mathrm{~mm}$ & $1 \mathrm{~mm}$ & 4 \\
\hline
\end{tabular}

substantially, ${ }^{8}$ with the reduction of dental and skeletal bimaxillary protrusion. ${ }^{2}$ After removing the appliances and placing new retainers, the patient was referred to dental whitening and composite restoration of the incisal borders of the upper anterior teeth. Thus, after the recommended procedures, an even more pleasant smile was obtained, which contributed significantly for the patient's complete satisfaction. ${ }^{6}$
REFERENCES

1. Almeida FM, Siqueira VCV. O efeito da exodontia dos primeiros pré-molares sobre a AFAI. Rev Dental Press Ortod Ortop Facial. 2004;9(6):48-62.

2. Bills DA, Handelman CS, BeGole EA. Bimaxillary dentoalveolar protrusion: traits and orthodontic correction. Angle Orthod. 2005;75(3):333-9

3. Bravo LA. Soft tissue facial profile changes after orthodontic treatment with four premolars extracted. Angle Orthod. 1994;64(1):31-42

4. Erdinc AE, Nanda RS, Dandajena TC. Profile changes of patients treated with and without premolar extractions. Am J Orthod Dentofacial Orthop. 2007:132(3):324-31.

5. Kim TK, Kim JT, Mah J, Yang WS, Baek SH. First or second premolar extraction effects on facial vertical dimension. Angle Orthod. 2005;75(2):177-82

6. Maltagliati LA, Montes LAP. Análise dos fatores que motivam os pacientes adultos a buscarem o tratamento ortodôntico. Rev Dental Press Ortod Ortop Facial. 2007:12(6):54-60.

7. Mohandesan H, Ravanmehr H, Valaei N. A radiographic analysis of external apical root resorption of maxillary incisors during active orthodontic treatment. Eur J Orthod. 2007:29(2):134-9.

8. Oliveira GF, Almeida MR, Almeida RR, Ramos AL. Alterações dentoesqueléticas e do perfil facial em pacientes tratados ortodonticamente com extração de quatro primeiros pré-molares. Rev Dental Press Ortod Ortop Facial. 2008;13(2):105-14.

9. Simplício H. Avaliação da reabsorção radicular apical em incisivos submetidos à retração [tese]. Araraquara (SP): Universidade Estadual Paulista; 2002 